\title{
EFFECT OF PELLET CONTAINING CASSAVA LEAVES MEAL AT VARIOUS PARTICLE SIZE ON BROILER
}

\author{
R. Noviadi and A. A. Candra* \\ Department of Animal Husbandry, State Polytechnic of Lampung, Indonesia
}

\begin{abstract}
The addition of cassava leaves meal (CLM) in broiler rations in the form of pellets require specific and uniform size because it will determine the characteristics of the material, especially the particle size plays an important role during the process of making ration (mixing and pelleting process). Research has been conducted from March to October 2013 in the Laboratory of the Department of Animal Husbandry. The study aims to look at the characteristics of the pellet that containing cassava leaves meal by using a variety of screen sizes as well as its influence on metabolizable energy, nutrient digestibility, histology of the digestive tract and broiler performance. Research using a completely randomized design (CRD), with three treatments and seven replicates and each experimental unit consisted of nine broilers. The treatment applied is T1 $=$ CLM milled using screen of $2 \mathrm{~mm}$, T2 = CLM milled using screen of $3 \mathrm{~mm}$, and T3 = CLM milled using screen of $5 \mathrm{~mm}$. Observations included physical characteristics of the pellets, nutrients digestibility, metabolizable energy, histology of ileum and broiler production performance. The data obtained were tested by analysis of variance and a further test using Duncan's multiple range test. The results showed that CLM milled using $2 \mathrm{~mm}$ screen to produce a compact pellet characteristics and performance of broiler production is better than the screen size 3 and $5 \mathrm{~mm}$ and the pellet with CLM milled using a screen 2 , 3 , and $5 \mathrm{~mm}$ produce normal ileal tissue in broiler.
\end{abstract}

Keywords: Pellet, cassava leaves meal, particle size and broiler

\section{INTRODUCTION}

The use of cassava leaves meal as a protein source in broiler rations in tropical countries such as Indonesia it is possible to lower the price of the ration. The main obstacle the cassava leaves meal is bulky nature. Consequences of this nature requires a larger container, difficult homogeneous if mixed with other feed ingredients and pellets produced easily broken. Efforts should be made to overcome the bulky nature is to reduce the particle size.

Reduction of particle size of materials relating to the technical and economic aspects. Amerah et al. (2007) explain that in general, small particle size will provide better effect, but not to the size that is too smooth. So it can be seen that each level of broiler age needs specific feed particle size. Nir and Ptichi (2001) recommended that from the age of day old chick to the finisher, broiler tend to require increased particle size. Koch (1996) stated that there is a practical limit to the degree of grinding material, it can be explained that the birds would have difficulty in consuming material that is too smooth or too coarse. The importance of knowing the optimal particle size of each phase is to determine the effective size required. This is because in the industry, shrink the size of the particles means increasing production costs.

Particle size of the feed material as a result of the grinding process affect the characteristics of the material such as size, particle shape, density and pellet durability index values. These characteristic changes will affect the efficiency of the handling, storage and further processing of products (Ruttloff, 1981). Material characteristics, especially particle size plays an important role during the manufacturing process poultry rations, especially when mixing and pelleting process. This process requires specific materials and uniform size, because it will relate to the next process. Goodband et al. (2002) explained that particle size reduction will increase the process efficiency and quality of feed pellets.

In addition to the above, the feed particle size relates to the efficiency of nutrient digestibility and affects the performance of poultry. Parsons et al. (2006) stated feed particle size reduction increases the surface area of the material so that the interaction between the digestive enzyme with increasing nutrients. Lott et al. (1992) in his research using particle size ration 3.18 and $9.59 \mathrm{~mm}$ in broiler age 1-21 days reported significantly higher body weight and feed conversion ratio is increased in particle size $3.18 \mathrm{~mm}$.

*Corresponding e-mail address: adicandra@polinela.ac.id 


\section{R. Noviadi and A. A. Candra}

The positive effects of feed particle size on gizzard developments associated with increased activity of milling, resulting in an increase in bowel movement and digestion of nutrients were greater. Although, grinding fine particle size material is expected to improve pellet quality, however, will significantly increase the energy consumption during the process. The research aims to conduct a systematic investigation to understand the relationship of particle size and pellet quality, intestinal health, productivity and efficiency optimal broiler with respect to the energy expenditure of milling.

\section{MATERIALS AND METHODS}

A total of 189 day-old male and female arbor acres 707 broiler chicks used in the study were care for 30 days. Rations and drinking water provided ad libitum. Cassava leaves were used in the study came from various varieties aged 8-10 months was taken from the experiment station of State Polytechnic of Lampung. Cassava leaves treated with a combination of chopping $2-3 \mathrm{~cm}$, wilting 24 hours at room temperature, and drying it under the sun for 2 days (Gomez and Valdivieso, 1985). Milling cassava leaves and other feed ingredients in the form of grain using semi-fixed a hammer mill machine with a screen 2,3 , and $5 \mathrm{~mm}$, while the feed material in the form of mash not grinded. Treatment ration composed with $23 \%$ protein content with metabolizable energy level of $3,000 \mathrm{kcal} / \mathrm{kg}$ (Table 1). The pellets made with vertical pellet machine with a capacity of $100-150 \mathrm{~kg}$ per hour, using a die diameter of 2 and $4 \mathrm{~mm}$.

Table 1. Treatment rations

\begin{tabular}{ll}
\hline Feed ingredients & Formulations (\%) \\
Yellow Corn & 46.00 \\
Coconut Oil & 3.50 \\
Rice bran & 2.50 \\
Soy bean meal & 27.00 \\
Fish Meal & 7.00 \\
Copra meal & 3.00 \\
CLM & 7.50 \\
Cassava waste product & $3: 50$ \\
\hline & 100.00 \\
\hline Matabolizable energy $(\mathrm{kcal} / \mathrm{kg})$ & $2,996,46$ \\
Crude protein $(\%)$ & 23.11 \\
Crude fat (\%) & 6.31 \\
Crude fiber $(\%)$ & 5.52 \\
Calcium $(\%)$ & 1.00 \\
Phosphorous $(\%)$ & 0.46 \\
\hline
\end{tabular}

The determination of nutrient digestibility and metabolizable energy

Nutrient digestibility determination of dry matter and crude protein ration by taking digesta from the ileum further analyzed proximate (AOAC, 1995). Digestibility value calculation through methods of Coen et al. (1996) with indicator lignin (Van Soest, 1994). Determination of metabolizable energy ration refres to Sibbald and Morse (1983) by accommodating excreta for 24 hours and then analyze its gross energy with Oxygen Bomb Calorimeter.

\section{Experimental design and data analysis}

Research using a completely randomized design (CRD), with three treatments and seven replications rations and each experimental unit consisted of nine broilers. The treatment applied is R1 = CLM milled using screen of $2 \mathrm{~mm}, \mathrm{R} 2=$ CLM milled using screen of $3 \mathrm{~mm}$, and R3 = CLM milled using screen of $5 \mathrm{~mm}$. Observation include the physical characteristics of the pellets, nutrients digestibility, metabolizable energy, histology of ileum, and broiler production performance. Data were subjected to ANOVA (Steel and Torie, 1996). If the main effect for diets was significant, means were separated by Duncan's multiple range test. 


\section{RESULTS AND DISCUSSION}

The average value of the characteristics of the pellets that containing cassava leaves meal in a variety of screen sizes are presented in Table 2. Results of measurement of durability shows the range of 75.286-97.314\%. The results showed highly significant differences $(\mathrm{P}<0.01)$ in the value of pellet durability index (PDI) with a variety of treatments are used (Table 2). Duncan's multiple range test results showed that the value generated by the treatment of P1 $(2 \mathrm{~mm}$ screen) differs very significantly higher $(\mathrm{P}<0.01)$ compared with treatment $\mathrm{P} 2$ (screen $3 \mathrm{~mm}$ ) and P3 (screen $5 \mathrm{~mm}$ ). Data from the calculation of nutrient digestibility and metabolizable energy pellets is presented in Table 3. Dry matter digestibility, crude protein digestibility and metabolizable energy were significantly influenced by treatment $(\mathrm{p}<0.05)$.

Table 2. Characteristics of pellets

\begin{tabular}{llll}
\hline Variables & \multicolumn{3}{c}{ Treatment } \\
\cline { 2 - 4 } & P1 $($ screen $2 \mathrm{~mm})$ & P2 $($ screen 3 mm) & P3 $($ screen 5 mm) \\
\hline Specific weight $\left(\mathrm{kg} / \mathrm{m}^{3}\right)$ & $632.00^{\mathrm{a}}$ & $608.00^{\mathrm{a}}$ & $628.714^{\mathrm{a}}$ \\
Compacted bulk density $(\mathrm{m} / \mathrm{sec})$ & $2.245^{\mathrm{a}}$ & $2.202^{\mathrm{a}}$ & $2.182^{\mathrm{a}}$ \\
Particle Size $(\mathrm{cm})$ & $0.057^{\mathrm{a}}$ & $0.063^{\mathrm{a}}$ & $0.089^{\mathrm{b}}$ \\
Density & $1.029^{\mathrm{a}}$ & $1.029^{\mathrm{a}}$ & $1.033^{\mathrm{a}}$ \\
PDI $(\%)$ & $97.314^{\mathrm{a}}$ & $95.143^{\mathrm{b}}$ & $75.286^{\mathrm{c}}$ \\
\hline
\end{tabular}

The same superscript letters indicate not significantly different $(\mathrm{P}<0.05)$

Table 3. Digestibility nutrients and metabolizable energy of pellet

\begin{tabular}{llll}
\hline Variables & \multicolumn{3}{c}{ Treatment } \\
\cline { 2 - 4 } & P1 (screen 2 mm) & P2 (screen 3 mm) & P3 (screen 5 mm) \\
\hline Dry matter digestibility (\%) & $55.195^{\mathrm{a}}$ & $53.804^{\mathrm{b}}$ & $4.991^{\mathrm{c}}$ \\
Crude Protein Digestibility (\%) & $72.539^{\mathrm{a}}$ & $67.478^{\mathrm{b}}$ & $66.512^{\mathrm{c}}$ \\
Metabolizable energy $(\mathrm{kcal} / \mathrm{kg})$ & $2,990.273^{\mathrm{a}}$ & $2,975.241^{\mathrm{a}}$ & $2,899.876^{\mathrm{b}}$ \\
\hline
\end{tabular}

The same superscript letters indicate not significantly different $(\mathrm{P}<0.05)$

Ileum histological observations in the digestive tract of broilers that consumed pellet that containing CLM in a variety of screen sizes are presented in Figures 1, 2, and 3.

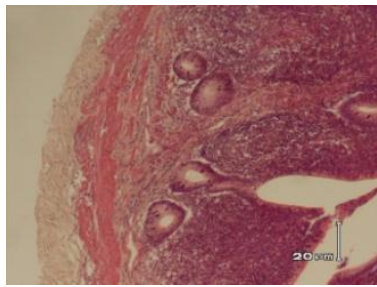

Figure 1. P1 (screen $2 \mathrm{~mm})$

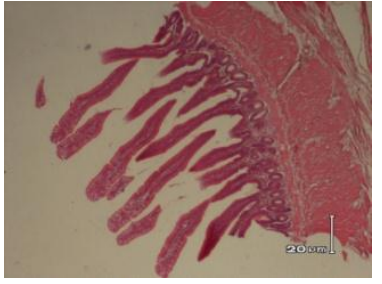

Figure 2. P1 (screen $3 \mathrm{~mm})$

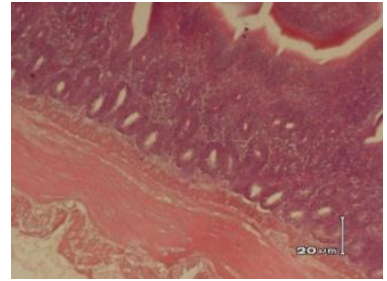

Figure 3. P3 (screen $5 \mathrm{~mm}$ )

Broiler productivity that consuming pellet that containing CLM in a variety of screen sizes are presented in Table 4. There were no significant difference $(\mathrm{p}>0.05)$ in feed intake, body weight and feed conversion ratio between P1 (screen $2 \mathrm{~mm}$ ) and P2 (screen $3 \mathrm{~mm})$, but there were significant difference $(\mathrm{p}>0.05)$ in body weight and feed conversion ratio on $\mathrm{P} 3$ (screen $5 \mathrm{~mm}$ ).

Table 4. Broiler productivity maintained for 30 days.

\begin{tabular}{llll}
\hline Variables & \multicolumn{3}{c}{ Treatment } \\
\cline { 2 - 4 } & P1 (screen 2 mm) & P2 (screen 3 mm) & P3 (screen 5 mm) \\
\hline Feed intake (g/bird) & $1,799.787^{\mathrm{a}}$ & $1,854.073^{\mathrm{ab}}$ & $1,905.105^{\mathrm{b}}$ \\
Body weight $(\mathrm{g} / \mathrm{bird})$ & $1,253.143^{\mathrm{a}}$ & $1,216.570^{\mathrm{a}}$ & $1,111.000^{\mathrm{b}}$ \\
Feed conversion ratio & $1.439^{\mathrm{a}}$ & $1.530^{\mathrm{a}}$ & $1.718^{\mathrm{b}}$ \\
\hline
\end{tabular}

Note: The same superscript letters indicate not significantly different $(\mathrm{P}<0.05)$ 


\section{R. Noviadi and A. A. Candra}

Pellet Durability Index (PDI) is a value that shows the amount of endurance (durability) of a material (feed pellet form). Particle size $<2 \mathrm{~mm}$ produces the highest PDI value compared with other treatments (Table 2). According to Dozier (2001), the value of broiler pellet durability for is a minimum of $80 \%$. This value indicates that the pellet in this study include pellet is strong and not easily broken during handling and transport (transport). Pellet strong, sturdy, and not easily crushed to meet the tastes of consumers (farmers).

The particle size of materials affects the value of PDI pellets. This is in accordance with the opinion of Waldroup (2005) that the particle size of the material may affect the integrity (integrity) or endurance (durability) pellets. Ration material finer and smaller-sized particles can produce a compact and dense pellet. This is in accordance with Behnke (1994) that the particle size and texture of a soft material can produce a compact and dense pellets because it has a large surface that is easy to absorb and accept hot water. Further explained by Reimer (1992), pellet quality is influenced by the particle size of the material by $20 \%$. A decrease in particle size of materials from fine to coarse size will increase the surface area per unit volume for the absorption of water vapor when evaporation.

P1 (2 mm screen) has the size finer textured material so that when the pelleting more good starch derived from cassava leaves meal and other ingredients that gelatinizes by engine heat into the adhesive on the printing process. Adhesive resulting from the gelatinization process will help improve the process of gluing the particles in the pellet thus increasing the resilience of pellets. As a result, the value of PDI in P1 (screen $2 \mathrm{~mm}$ ) greater than P2 (screen $3 \mathrm{~mm}$ ) and P3 (screen $5 \mathrm{~mm}$ ). This is in accordance with the opinion of Rasidi (1997) that the smaller the size of the feed materials making up rations will further support the hardness and durability of pellets produced.

P1 (2 mm screen) has a dry matter digestibility values were highest among other treatments, the above results indicate that the smaller the particle size CLM, then increasing the value of dry matter. Amerah et al. (2007) stated that the feed material particle size reduction will increase the surface area of the material so that the greater access of digestive enzymes. It is responsible for nutrient digestibility speed that will increase the value of digestibility. Freedriksz et al. (2003) reported that the particle size of the feed material $<2 \mathrm{~mm}$ affect the process of degradation of nutrients compared to the size of $>2 \mathrm{~mm}$.

Value of digestibility of crude protein in the pellet P3 (screen $5 \mathrm{~mm}$ ) lower than P1 (2 mm screen) and P2 (screen $3 \mathrm{~mm}$ ). This indicates that a large particle size will reduce the surface area so that access increasingly constrained protein digestive enzymes. Anggorodi (1979) explains that crude protein digestion occurs when food associated with the enzyme pepsin from gastric juice, pepsin break down proteins into simpler cluster that is proteosa and peptone. This protein digestibility process can take place optimally if the enzyme pepsin gets access to all the feed particles. However, if the enzyme pepsin less gain access as a result of the particle size of pellet feed material that containing CLM at P3 bigger (screen $5 \mathrm{~mm}$ ) compared to P1 and P2, the process of protein digestion will be decreased. Feed Tech (2009) explains that the increase in the size of the feed particles per 100 $\mu \mathrm{m}$ will reduce nitrogen digestibility values of 0.8 units.

Metabolizable energy value of P1 pellets (screen $2 \mathrm{~mm}$ ) and P2 (screen $3 \mathrm{~mm}$ ) was significantly different from the size of P3 (screen $5 \mathrm{~mm}$ ). This is related to nutrient digestibility value. Causing high digestibility of energy utilized by the body more chicken and less is lost through feces. This shows the close relationship between the metabolizable energy digestibility (McDonald et al., 1978). Improved digestibility of crude protein closely related to the increase in the value of metabolic energy, because increased decomposition of the feed nutrients also increases the energy source components in the body of cattle that can be utilized.

Figure 1,2, and 3 showed that the ileum in normal tissue structure and no significant changes. From these observations may further explain that each treatment had the same effect on the histology of the small intestine of broilers. Keith et al. (2013) stated that the physical a stimulating effect on the digestive tract to increase the use of nutritional origin pelleted feed.

Table 4 shows that the larger the particle size of cassava leaf meal in the higher grades of pellets produced feed consumption. But this does not indicate a synergistic relationship between high consumption with body weight gain of broilers produced. Broiler body weight gain is closely related to the value of ration digestibility. The higher digestibility of the ration, the more nutrients are digested and absorbed by the body for the sake of tendon tissue formation.

Feed conversion value is closely related to the value of feed intake and body weight gain. Table 4 shows that the larger the particle sizes the higher value material pellet feed conversion. High feed conversion in treatment 
P3 caused by the high value feed consumption but produces lower body weight gain. It is influenced by low nutrient digestibility value especially digestibility of crude protein. Behnke (1994) states that the feed pellet form can improve the performance of poultry and feed conversion by increasing palatability and lower residual feed that is not consumed. Food remains small and good feeding management is a major factor increasing of feed efficiency.

Cassava leaves meal are ground using a $2 \mathrm{~mm}$ screen to produce a compact pellet characteristics and Performance of broiler production is better than the screen size 3 and $5 \mathrm{~mm}$, and the pellet that containing CLM are milled using a screen 2,3 , and $5 \mathrm{~mm}$ produce ileum were normal in the broiler.

\section{REFERENCES}

1. Amerah AM, Ravindran V, Lentle RG and Thomas DG (2007). Feed particle size: Implications on the digestion and performance of poultry. World's Poultry Science Journal 63: 439-455.

2. Anggorodi R (1979). General Feed Science. Gramedia.co. Jakarta.

3. AOAC (1995). Official methods of analysis. 16th Ed. Association of Official Analytical Chemists. Washington DC

4. Behnke K (1994). Factors Affecting Pellet Quality. Maryland Nutrition Conference. Dept. of Poultry Science and Animal Science. College of Agriculture. University of Maryland. College Park.

5. Coen HM, Smits, Chanel AA, Maarsen, Johan, MVM, Mouwen and Jos FJG Koninkx (1996). The Effect of a carbocymethylcellulose antinutritive with high viscosity in broiler chickens is not associated with mucosal damage. In: Viscosity of dietary fibre in relation to lipid digestibility in broiler chickens. Proefchrift pp.71-79.

6. Dozier WA (2001). Pellet quality for more economical poultry meat. Journal of Feed International 52: 40-42.

7. Feed Tech (2009). Processing Nutritional effects of fine grinding feeds. 6. www.AgriWorld.nl.

8. Freedriksz M, Soejono and Fertile Priyono SB (2003). Effect of particle size and laundering against degradation in sacco few feed ingredients in peranakan Friesian cattle Holstein: effect of particle size and rinsing technique on in sacco degradation of some feeds stuff in. Prociding Agrosains 2003, XVI (2).

9. Gomez G and Valdivieso M (1985). Cassava foliage: chemical composition, cyanide content and effect of drying on cyanide elimination. Journal of the Science of Food and Agriculture 36: 433-441.

10. Goodband RD, Tokachi MD and Nelssen JL (2002). The effects of dietary particle size on animal performance. MF-2050 Feed Manufacturing, Department of Grain Science and Industry, Kansas State University. pp. 6.

11. Keith C, Behnke and Scott Beyer R (2013). Effect of feed on broiler processing performance. Kansas State University in Manhattan. Kansas.

12. Koch K (1996). Hammer mills and roller mills. MF-2048 Feed Manufacturing, Department of Grain Science and Industry, Kansas State University. 8 pp.

13. Lott BD, Day EJ, Deaton JW and May JD (1992). The effect of temperature, dietary energy level, and corn particle size on broiler performance. Poultry Science 71: 618-624.

14. McDonald RA, Edwards and Grenhalg JFD (1978). Animal Nutrition, 2nd.Ed. The English Language Book Society and Longman. pp. 190-200.

15. Nir I and Ptichi I (2001). Feed particle size and hardness: Influence on performance, nutritional, behavioral and metabolic aspects. In: Proceedings of the 1st World Feed Conference, Utrecht, the Netherlands. pp. 157-186.

16. Parsons US, Buchanan NP, Blemings KP, Wilson ME and Mortiz JS (2006). Effect of corn particle size and pellet texture on broiler performance in the growing phase. Journal of Applied Poultry Research 15: 245-255.

17. Reimer L (1992). Conditioning. Proc. Northern crops feed mill management institute and feed manufacturing tehnol. Short course p.7. California Pellet Mill Co. Crawfordsville, IN.

18. Rasidi (1997). 302 Local Feed Formulation Alternatives for Poultry. Spreader Organization, Jakarta.

19. Ruttloff C (1981). Mischfuttertechnologie. VEB Fachbuchverlag, Leipzig.

20. Steel RGD and Torrie JH (1995). Principles and procedures of statistics. (With special reference to the Biological Sciences.) McGraw-Hill Book Company, New York, Toronto, London.

21. Sibbald IR and Morse PM (1983). The Effect of nitrogen correction and feed intake on true metabolizable value. Poultry Science 62: 138-142.

22. Van Soest PJ (1994). Nutrition Ecology of the ruminants. 2nd Ed. O and B Books, Inc. Corvalis. New York: Cornell University Press.

23. Waldroup DW (2005). Particle size of grains and its significance in poultry nutrition. http://www.asasea.com. 